\title{
レーザー航跡場加速器の実用化に向けた課題と開発現状
}

\author{
中新 信彦 1,2 , 益田 伸一 ${ }^{1,2}$, 細貝 知直 ${ }^{1,2}$ \\ ${ }^{1}$ 大阪大学光科学センター ( $565-0871$ 大阪府吹田市山田丘2-1) \\ ${ }^{2}$ 科学技術振興機構CREST ( ₹ 565-0871 大阪府吹田市山田丘2-1)
}

\section{Current Status of Development of Laser Wakefield Accelerator towards Practical Use}

\author{
Nobuhiko NAKANII, ${ }^{1,2}$ Shin-ichi MASUDA,,${ }^{1,2}$ and Tomonao HOSOKAI ${ }^{1,2}$ \\ ${ }^{1}$ Photon Pioneers Center, Osaka University, 2-1 Yamada-oka, Suita, Osaka 565-0871 \\ ${ }^{2}$ Japan Science and Technology Agency (JST), CREST, 2-1 Yamada-oka, Suita, Osaka 565-0871
}

(Received August 24, 2012)

\begin{abstract}
Laser wakefield accelerator is expected to be one of the novel accelerators for a new energy frontier and an ultrashort electron source for many attractive applications such as ultrafast electron microscopy. In recent studies, pointing stability of an electron beam emitted from laser wakefield acceleration has been extremely improved by applying an external magnetic field to preplasma. Emission direction of the electron beam can be controlled by the direction of the magnetic field. This stable and controllable electron beam can be a precise injector of staged laser wakefield acceleration and the energy spectrum of electron bunch can be modified by further acceleration and phase rotation in next wakefield. Also conventional beam optics is available for such stable electron beam. We are developing a reliable laser wakefield accelerator/electron source based on staged laser wakefield acceleration and new ultrashort electron bunch transport system with conventional beam optics towards practical use.
\end{abstract}

Key Words: Stable injector, Staged laser wakefield acceleration, Ultrashort electron bunch transport

1.はじめに

レーザー航跡場加速 (Laser Wakefield Acceleration: LWFA) は超短パルス高強度レーザーによって励起される電子プ ラズマ波が持つ極めて高い加速勾配を利用した粒子加速 法であり, 次世代の超高エネルギー加速器として期待さ れている. 一方, 近年の物性材料科学研究では物質の高 速過渡現象解明のため, 極短かつ電荷量が大きい高品質 な電子バンチがプローブビームとして必要とされてお り, LWFAがもつ極短パルス性, 大電荷量, 低エミッ夕 ンス性等のビーム源としての高いポテンシャルが注目さ れている.

LWFAは1979年にTajimaとDawsonによって提唱されて から30余年が経過し ${ }^{1}$, 研究開始当初の目標であった準 単色ビーム発生や $\mathrm{GeV}$ の電子加速は世界各国の研究機関 で既に実証されてきた ${ }^{2,3)}$ ，現在は更なるエネルギーフ ロンティアに向かって研究開発競争が進んでいる。それ にもかかわらず，ユーザが利用可能なレーザー航跡場加 速器は未だに存在しない. 現実的な加速器としてLWFA を考えるとき, 従来の高周波加速器並みの高い信頼性と 制御性が必要なのは言うまでもない. 高エネルギー加速 器分野のみならず物性材料科学等の応用研究分野からも
LWFAに大きな期待が寄せられている今，その実現は急 務である.

これまでの研究で高強度レーザーのプレパルスによっ て生成されるプレプラズマがメインパルスの伝播と集光 を阻害し, 電子ビームの発生の安定性に大きく影響する ことが明らかにされてきだ,5)。近年, 著者らは磁場を 用いてプレプラズマの挙動を制御し，高強度レーザーパ ルスの伝播を制御する手法を考案・実証し，非常に安定 な入射用電子源の開発に成功した6)。レーザー航跡場へ の電子入射はLWFAにおいて制御が難しい大きな課題の 一つであり，この安定な電子入射技術の確立によって多 段レーザー航跡場加速が現実味を帯びてきた。

本稿では，現在著者らが取り組んでいる応用研究への 実用化を目指した多段レーザー航跡場電子加速による高 品質電子源の開発状況について概説する7,8). また, 電 子入射の安定性と制御性の劇的な向上によって, 従来加 速器で用いられる電磁石などのビーム輸送技術の使用が 可能になった。このビームオプティクスを使用したエネ ルギー分散を持つフェムト秒電子バンチの輸送システム についても紹介する7). 


\section{2. 多段レーザー航跡場による電子加速}

\section{1 自己入射方式のレーザー航跡場加速}

LWFAにおいて高品質ビーム生成の鍵となるのはレー ザー航跡場への電子入射である。電子がプラズマ波 (レーザー航跡場)に捕獲され加速されるためには, あら かじめ相対論的エネルギーまで加速した電子バンチが航 跡場の加速位相に入射される必要がある。 ガス標的に集 光された超短レーザーパルスはFig. 1に示すようにレー ザーの進行方向と半径方向に電場を励起するが，これら

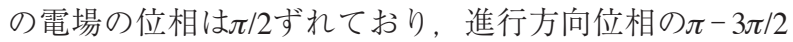
の区間に電子バンチを入射できれば電子バンチが発散す ることなく軸方向へ効率的に加速される。このとき入射 電子のバンチ長はプラズマ波長の $1 / 4$ 以下でなければな らない。実際には, LWFAの典型的なプラズマ波長は 10-100 $\mu \mathrm{m}$ 程度なので, 時間幅が $6-60 \mathrm{fs}$ 程度, 空間的 にも2-20 $\mu \mathrm{m}$ 程度の極短電子バンチを生成して加速可能 な位相に整合するように入射しなければならない。

LWFA研究黎明期においては, 電子入射に高周波加速 器が用いられたものの ${ }^{9)}$, この航跡場の非常に狭い位相 への電子入射の要求を満足する極短パルス超低エミッタ ンス電子ビーム発生の困難さと, 高周波加速器とレー ザー航跡場のフェムト秒オーダの同期が大きな技術的課 題となり ${ }^{10)}$, 現在は従来加速器を用いない自己入射 (Self-injection)型の電子入射が主流である ${ }^{11,12)}$.

自己入射方式の電子入射では，超短パルスレーザーを 用いて背景プラズマ電子を航跡場の加速位相に直接入射 させるが，その中で最も簡単かつ現実的なものは，非線 形プラズマ波の破砕による電子入射法である ${ }^{13)}$ 。相対論 的なプラズマにおいて(位相速度が光速 $c に$ 近いプラズマ 波を相対論的プラズマ波と呼ぶ. ) , プラズマ波はその振 幅がしきい值 $E_{B} \sim\left[2\left(\omega / \omega_{p}-1\right)\right]^{1 / 2} m c \omega_{p} / e$ を越えると破砕 する ${ }^{14)}$. ここで $\omega, \omega_{p}$ はそれぞれレーザーとプラズマ振 動数を, $m, c, e$ はそれぞれ電子の質量, 光速, 電荷素 量を示す。この方法では非線形プラズマ波の成長に依存 するため波破砕を制御することが難しい. これに対して プラズマ中に急峻な密度勾配があるときにはこの密度境 界でも局所的にプラズマ波破砕が起きる ${ }^{15)}$. この場合は

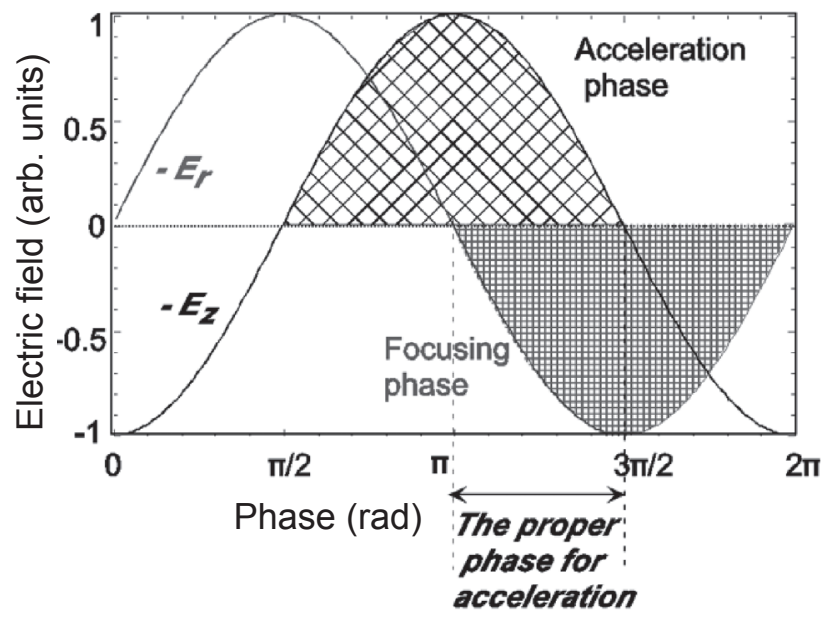

Fig. 1 Longitudinal and radial electric field.
線形プラズマ波でも破砕が可能であり，より安定な入射 が期待できる．急峻な密度勾配を作るために様々な方法 が提案されており，この密度勾配を利用した電子入射も 報告されている ${ }^{16-18)}$.

\section{2 多段レーザー航跡場加速}

自己入射方式のLWFAにおいては，1つの高強度レー ザーパルスが駆動する非線形レーザー航跡場の中で電子 の入射と加速を連続的に行う。高強度レーザーパルスの 伝播は標的プラズマ中の密度分布に極めて敏感であるた め, プレプラズマなどの密度擾乱で回折し安定な電子入 射を得ることが難しいことに加えで,5), 被加速電子の ビームパラメータを精密に制御するためにはレーザー航 跡場の狭い位相への正確な電子入射が必要不可欠であ る。従って，1つのレーザーパルスによる詳細なビーム パラメータ制御は極めて困難であると考えられる。以上 のことから，安定かつ制御性の高い加速器を作るために は電子入射と加速を分け複数のレーザー航跡場 (入射電 子を発生するレーザー航跡場と加速を行うレーザー航跡 場）を独立に制御する多段加速がより現実的である.

Fig. 2 (a)に一般的な多段レーザー航跡場加速の基本 原理を示す．多段加速とは独立した複数の航跡場によっ て電子を段階的に加速するものであり，図に示すように 一つ目の航跡場で発生，加速した電子バンチをその後方 にある独立した航跡場に入射させ，さらなる加速を行 う。これまで多段加速は高エネルギー化を目的とした追 加速のために提案されており，LWFAによるもの以外に も従来加速器からの電子ビームをプラズマに入射して航 跡場を励起するプラズマ航跡場加速による多段加速 (追 加速)実験も行われている ${ }^{19)}$.

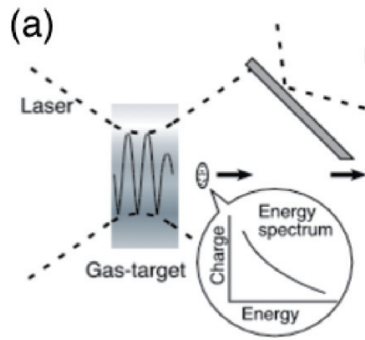

1st wakefield for injection

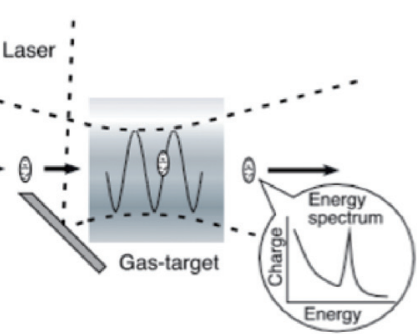

2nd wakefield for acceleration and phase rotation (b)

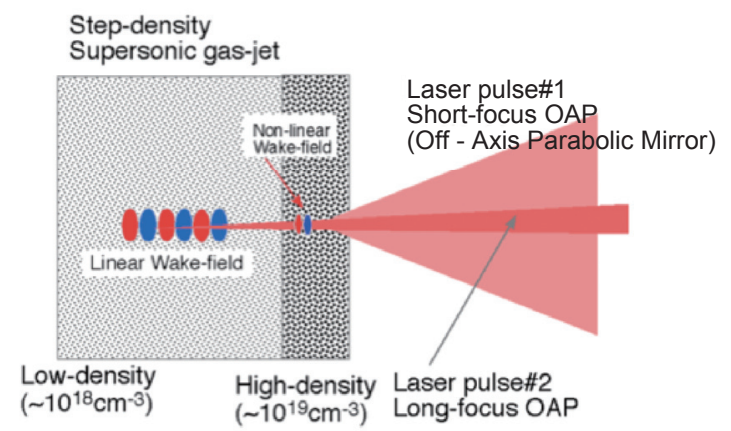

Fig. 2 (a) Typical staged laser wakefield acceleration. (b) Staged laser wakefield acceleration with stepdensity gas-jet target. 
一方，著者らはFig. 2 (b) に示すような階段状ガス ジェット標的を用いた多段加速法を提案している. ガス ジェット標的の高密度部分では短焦点集光のレーザーパ ルスで励起された非線形レーザー航跡場の波破砕によっ て後段航跡場への入射用電子を発生させる。高密度領域 の先にある低密度領域では長焦点集光のレーザーパルス によって長尺の線形航跡場を励起し後段の加速を行う. 急峻な密度境界面で効率の良い波破砕を起こすととも に，2つの航跡場を隣接させることによって後段への入 射効率のよい多段加速を行うことができると見込まれ る.

高エネルギー化を目的とした追加速のために提案され てきた多段加速だが，同期した2つのレーザーパルスの タイミングを制御し, 後段のレーザー航跡場の適当な位 相に正確に低エミッタンス極短電子バンチを入射するこ とができれば，位相回転による電子ビームスペクトルの 準単色化も可能である。例えば, 前方に減速位相, 後方 に加速位相がある境界部分に電子バンチが入射すると低 エネルギー成分は加速され, 高エネルギー成分は減速さ れるため, Fig. 2 (a)の吹出し中に示すようなエネル ギースペクトルの狭帯化が起こる，なお，位相回転では エネルギー幅が狭くなる一方, バンチ幅は多少伸びるが 航跡場の波長 (数十fs) 以下程度に維持される。このよう に，多段航跡場加速ではエネルギースペクトルの制御性 の高い極短パルス電子加速器/電子源の実現が期待でき る.

一般的にプラズマ波破砕から発生する入射電子は熱的 な幅広いエネルギースペクトルを持つ. Fig. 3に示すよ うに，熱的なスペクトル(一点鎖線)を持つ電子バンチを 後段のレーザー航跡場の適当な位相に入射させると, 位 相回転によってエネルギースペクトルを狭帯化でき, 入 射位相 $\phi[\mathrm{rad}]$ を選ぶことでピークの值も制御できること が数值計算によって確認されている $(\text { 点線と実線を参照 })^{8)}$.

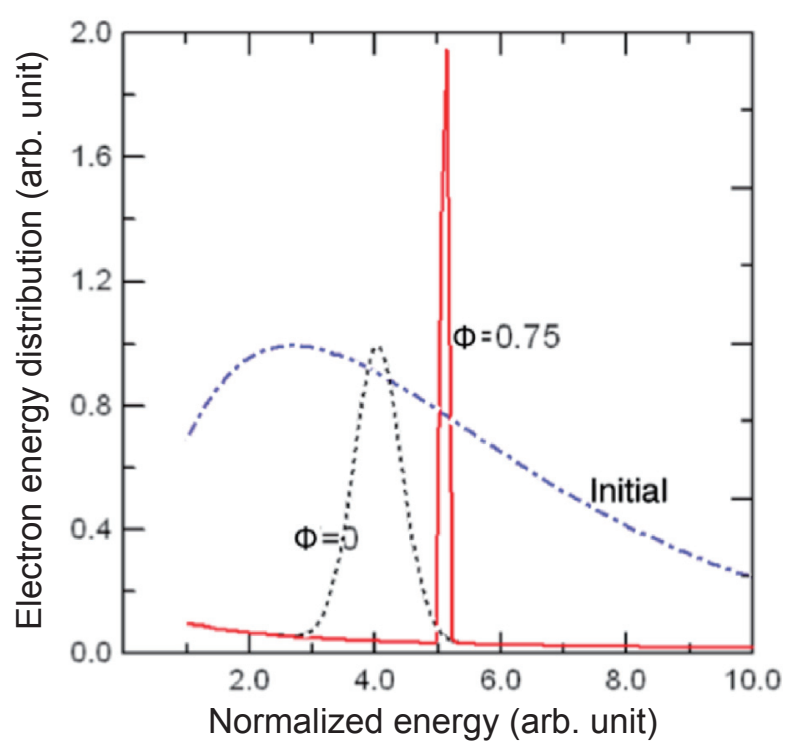

Fig. 3 Phase rotation of injected electron bunch in 2 nd laser wakefield.

\section{3. 電子入射器の現状}

多段加速の実現には航跡場の中の極めて狭い位相に正 確に電子バンチを入射させる必要があり，安定した低工 ミッタンス極短電子入射器が必要不可欠となる。近年, プレプラズマを積極的に利用した光導波技術の開発に よって, レーザー航跡場から発生する電子ビームの品質 と安定性が飛躍的に向上した。詳細は文献6）に譲るが, 本節ではレーザー航跡場加速におけるプレプラズマの影 響と磁場印加による電子ビームの安定生成の手法につい て紹介する。.

\section{1 レーザープレパルス効果}

一般に, CPA (Chirped Pulse Amplification)法を用いた 超短パルス高強度レーザーシステムより生成される数十 フェムト秒, 数十TWの高強度レーザーパルスの前方に はナノ秒〜ピコ秒オーダのプレパルスが存在する。この プレパルスが集光点付近に球状のプレプラズマを形成 し，高強度のメインパルスがこのプレプラズマによって 集光点の手前で回折され，集光強度が低下し集光スポッ トのプロファイルも悪化する。結果として, LWFAで発 生する電子の電荷量とエネルギーは低下，ビームは大き く飛散し，加えて再現性も乏しい，実際にプレパルスの 強度を小さくし，プレプラズマの発生を抑えることに よって電子ビームの指向性と安定性が向上するとの報告 がある ${ }^{20,21)}$. 最近ではプレパルス効果を完全に除去する ため, プレパルスフリーのCPAレーザーの開発も進めら れている22).

\section{2 安定な電子入射源開発}

一方，著者らはプレパルスによるプレプラズマを積極 的に用いることによって電子ビーム発生を安定化してい る. ガス標的内部の集光点付近のレーザー軸方向に平行 な磁場を印加し，さらに，プレパルスの大きさを適当に 調整することで, 電子ビームの指向性と位置安定性が劇 的に向上する。Fig. 4に安定した入射用電子発生の実験 配置を示す。シート形状の超音速へリウムガスジェット 標的を挟むように二つのリング状永久磁石を配置し，ガ スジェット内にレーザー伝播軸方向に約 $0.2 \mathrm{~T}$ の磁場を 印加する。リング状磁石の中心穴を通して高強度レー

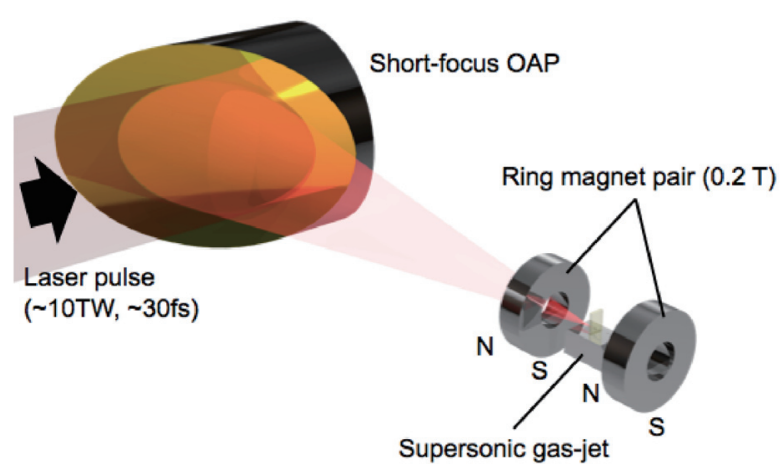

Fig. 4 Extremely stable electron beam generation with external magnetic field. 
ザーパルス $(\sim 10 \mathrm{TW}, \sim 30 \mathrm{fs})$ を標的ガス上に比較的短 焦点の軸外し放物面鏡 $(F$ 值〜 3.5) を用いて集光する。集 光強度は〜 $8.0 \times 10^{19} \mathrm{~W} / \mathrm{cm}^{2}$ で, ASE (Amplified Spontaneous Emission) プレパルスのメインパルスに対する典型的な コントラスト比は $10^{6} \sim 10^{7}$ 程度である。磁場を印加しな かった場合 $(B=0)$ と印加した場合 $(B=0.2 \mathrm{~T})$ に対して 得られた電子ビームの空間プロファイルをFig. 5 (a), （b）に示す。磁場を印加しない場合はFig. 5 (a)に示され るように電子ビームは広い領域に飛散し空間プロファイ ルの再現性もきわめて悪い.これは前節で述べたプレプ ラズマ効果によってメインパルスの集光が阻害されたた めである. 一方, Fig. 5 (b) の磁場を印加した場合は, 非常に指向性の高い電子ビームが発生する。このときの 横方向幾何学的エミッタンスは $0.02 \pi \mathrm{mm} \mathrm{mrad}$ 程度で, 総電荷量は $1 \mathrm{nC}$ 近くに達し, これは磁場を印加しない場 合 (a)の十倍以上の電荷量である。この電子のエネル ギースペクトルは熱的に広がっており, その有効電子温 度は〜25 MeVである。

Fig. 6 (1) - (6) に連続6ショットのビームプロファイ ルの再現性を示す. 磁場を印加した場合, 繰り返し ショットにおいても高品質なビームが再現性良く発生し ている。この電子ビームのエネルギースペクトルは熱的 に広がっているが，プラズママイクロオプティクスと呼 ばれる光導波技術を用いて長尺な航跡場を励起すること で，積極的な入射位相の制御は行えないものの，ポイン ティングの安定性と指向性の良さを維持したまま, チャ ネル内の航跡場によって電子が加速され, 同時に位相回 転によるエネルギースペクトルの準単色化も明確に観測 されている23).
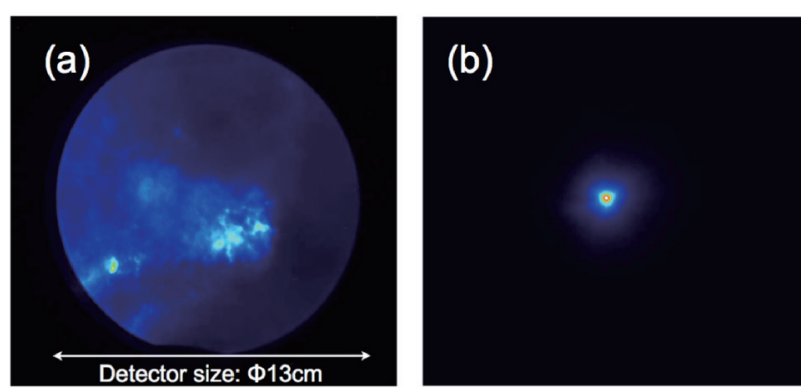

Fig. 5 Electron beam profiles. (a) $B=0$, (b) $B=0.2 \mathrm{~T}$.

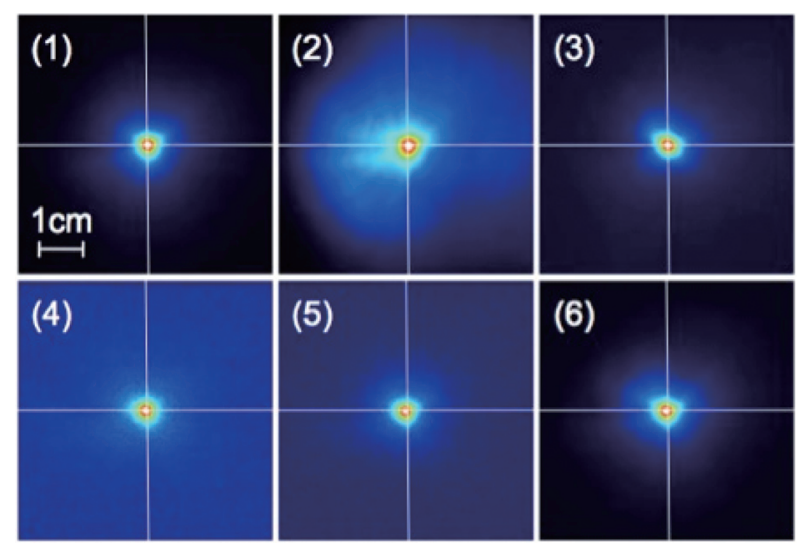

Fig. 6 Electron beam profiles of 6 successive shots. $B=0.2 \mathrm{~T}$.
このビーム品質と再現性の劇的な向上は磁場中でのプ レプラズマのダイナミクスに起因している，集光点付近 で $\omega_{L} t_{e i}>1$ (ただし, $\omega_{L}$ : ラーマー周波数, $t_{e i}$ : イオン 電子の衝突時間)の条件を満足するようなレーザー軸方 向の磁場を印加すると，焦点近傍の微小領域のプレプラ ズマのみが磁化し，膨張が抑制され密度が高い状態を維 持する。焦点から外れた磁化されていない部分は膨張す るため, 最終的に光導波特性を持つコーン形状のプレプ ラズマが形成される。メインパルスはこのコーンプラズ マ中を光導波され，密度の高いコーンの先端部に小さい スポット径を維持したまま高い強度で集光される．集光 点ではスポットサイズ程度の微小領域で強いプラズマ波 破砕が起こるようになり，指向性の良い大電荷の電子 ビームが発生する。この場合，レーザーパルスの回折が 抑制されるためプラズマ波破砕の発生点のずれもなく ビームの位置安定性は極めて高くなる ${ }^{6}$.

さらに, このプレプラズマによる光導波を用いた電子 入射器はポインティングの制御も可能であることが最近 明らかになった ${ }^{24)}$. Fig. 6で示した指向性の良いビーム は磁場の方向に正確に沿って放出される。Fig. 7に外部 磁場の方向を変化させたときの電子ビームプロファイル を示す． $0{ }^{\circ}$ をレーザー軸とし水平垂直方向に $3(2.5)$ 。 外部磁場を傾けた，外部磁場の方向を変化させると，電 子ビームの発生方向は外部磁場の方向に完全に沿って変 化するが，エネルギースペクトル・電荷量・エミッタン スは変化しない。これは磁場の方向を制御することに よって，電子のエネルギーに依存しないビームの方向制 御が可能であることを意味し，後段の航跡場への空間的 に正確な入射が可能であることを示している。この方式 は多段加速における電子入射器としての高い機能を有す る.

\section{4. 多段レーザー航跡場加速器開発現状}

現在, 著者らは安定な高品質極短電子パルスの発生を 目指し 3.2 節で述べた電子入射器をべースに二つの高強 度レーザーパルス駆動の多段レーザー航跡場加速のシス テムを構築中である ${ }^{7,8)}$. システムの概観をFig. 8に示 す。このシステムは高品質極短電子ビーム発生部(電子 入射器), ビームパラメータ制御(追加速, 位相回転によ

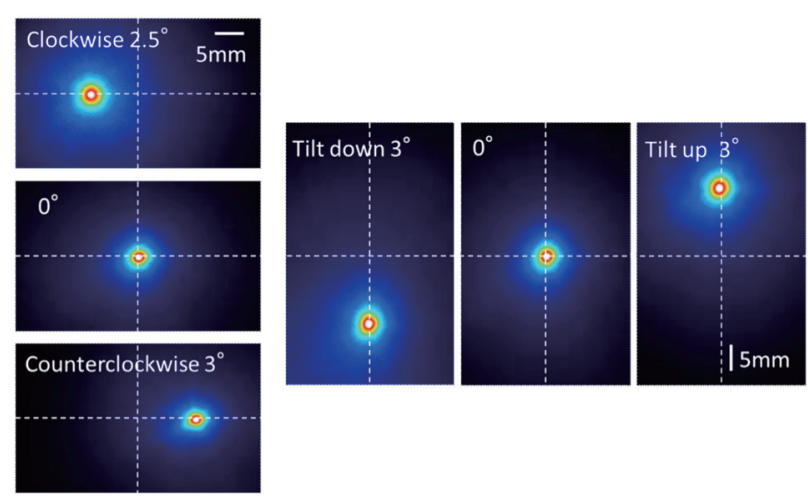

Fig. 7 Pointing control of electron beam by external magnetic field. $B=0.2 \mathrm{~T}$. 


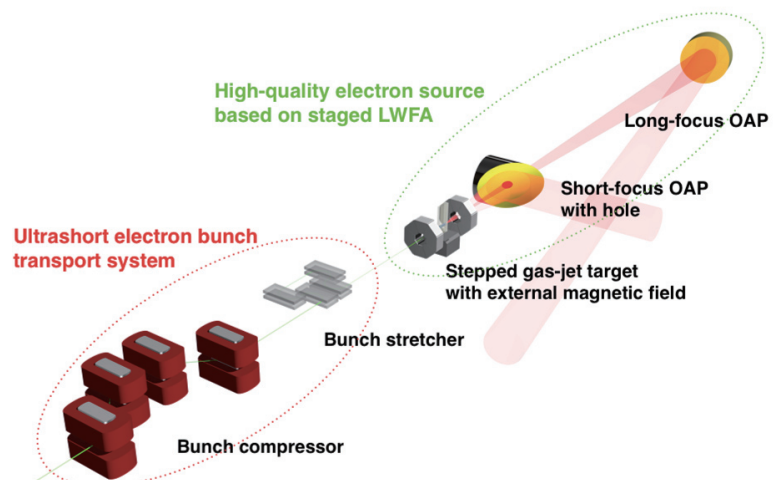

Fig. 8 High-quality repeatable electron source based on staged LWFA and the ultrashort electron bunch transport system.

るスペクトルの狭帯化など)のための後段レーザー航跡 場, さらに発生した極短電子バンチを任意の地点まで輸 送するために新たに開発している輸送系で構成されてい る.

\subsection{2 パルス駆動多段レーザー航跡場加速}

高品質極短電子ビーム発生部では前述の多段レーザー 航跡場加速を一つのガスジェット標的を用いて効率的に 行う。超音速スリットノズルの形状を工夫し, 意図的に 内部に衝撃波を駆動することでFig. 2 (b)に示したよう な急峻な密度勾配がある階段状密度のガスジェット標的 を開発した ${ }^{25)}$ ，そのガスジェット標的に入射用電子の安 定化を図るため, 磁石を配置し外部磁場を印加する. 光 同期可能な二つの高強度レーザーパルスを二種類の軸外 し放物面鏡 $(\mathrm{OAP})$ を用いて同軸で集光する。階段状ガス ジェット標的の高密度部分では短焦点のOAPでレーザー パルスを集光して励起した非線形レーザー航跡場の波破 砕によって入射用電子を発生させる. 高密度領域の先に ある低密度領域では長焦点のOAPで集光したレーザーパ ルスによって位相回転用の長尺の線形航跡場を励起す る。二つのレーザーパルス間にはジッターが存在しない ため同期の夕イミングを正確に調整することができる。 これにより, 電子バンチの航跡場への入射位相を正確に 制御することができ，発生する電子ビームのエネルギー やエネルギースペクトルなどのビームパラメータをコン トロールすることが可能となる. 実際の多段航跡場加速 実験を行う真空チャンバー内部の様子をFig. 9に示す. 2 つのパルスを同軸で集光するために中心軸上に穴のある 短焦点OAPを使用する.

\section{2 極短電子バンチ輸送}

LWFAから発生する電子バンチは, 発生点においては プラズマ波長以下程度 (数〜数十フェムト秒)の非常に短 いバンチ長を持つ. しかし, 高密度電子バンチの空間電 荷効果やエネルギー分散の影響により輸送される距離に ともないバンチ幅が大きく伸張してしまう. 応用研究等 にこの極短電子バンチを利用するためには, 電子発生点 における極短バンチ幅を任意の地点で得ることができる 輸送系を構築することが必要である。

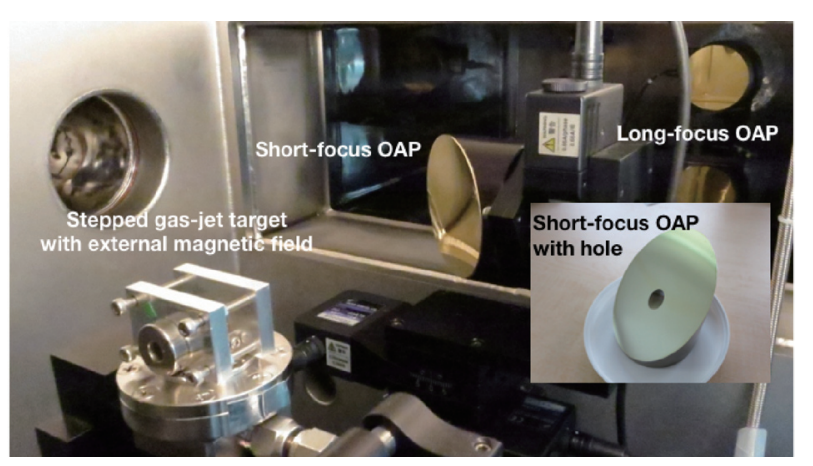

Fig. 9 Experimental setup of staged LWFA with two pulses.

これまでに述べたLWFAによる電子ビームの飛躍的な 位置安定性と指向性の向上によって, 従来加速器で使用 される四極磁石や偏向磁石などの磁気回路を用いたビー ム輸送技術が使用できるようになった。 LWFAから発生 するエネルギー分散を持つ大電荷でフエムト秒の電子バ ンチの輸送はこれまでに行われておらず，著者らは新し い極短電子バンチ輸送法を考案し, 現在構築中であ る7). Fig. 10に極短電子ビーム輸送系の概念図を示す. この輸送系は図に示すようなシケイン磁気回路からなる バンチストレッチャーとバンチコンプレッサーで構成さ れる。 まず，バンチストレッチャーによって正の時間分 散を与え, 低エネルギーの電子がバンチの前方に, 高エ ネルギーの電子が後方にくるように電子バンチ幅を伸長 する，続いて，極短バンチが必要な場所の直前に設置し たバンチコンプレッサーによってストレッチャーで与え た時間分散と輸送中の時間分散を相殺する負の時間分散 を与える分散補償を行い, バンチ圧縮を行う。このシス テムによってエネルギー分散によるバンチの伸張を補償 しつつ空間電荷効果も抑えて極短電子バンチを輸送する ことができる.さらに, 圧縮器の磁気回路を電磁石で構 成することでバンチ幅の調整も可能となる，著者らはこ れを極短レーザーパルスの生成法であるCPA法になぞら えチャープ電子バンチ輸送 (Chirped electron bunch transport: CeBT) と命名した.

このシステムは電子バンチの極短性を利用する応用研 究(例えば, 材料物性科学研究における超高速電子イ メージングなど)にとって必要不可欠であるが, エネル ギーフロンティア研究に向けた高エネルギー化への展開 においても，さらなる多段加速を行うために離れた別の 航跡場の狭い位相に極短電子バンチを入射するにはこの ようなシステムが必要となる。

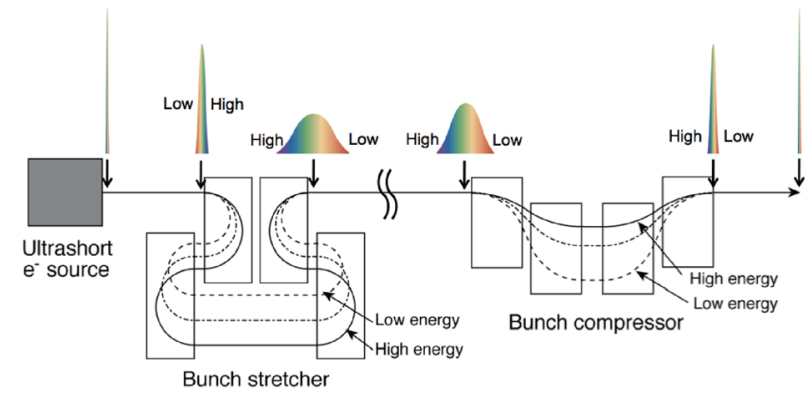

Fig. 10 Chirped electron bunch transport (CeBT). 


\section{5. まとめ}

本稿では, 信頼性の高い加速器・電子源の構築を目指 した多段レーザー航跡場による電子加速への取り組みに ついて概説した。 長年にわたる大勢の研究者達の努力に よってLWFAの粒子加速機構としての高いポテンシャル は実証されてきたものの, 現実的な加速器の実現は未だ に遠いと思われていた，LWFAは加速媒質にプラズマを 用いることから，本質的に不安定性を克服できないとの 悲観的な意見も未だ根強い。しかしながら，近年，レー ザープレパルス制御, 外部磁場印可, 光導波路, 安定な 超音速ガスジェットの開発等の要素技術開発の積み上げ と新たな知見の発見によって, 上うやく, 安定かつ制御 性の高いLWFA駆動の極短入射電子源が実証されつつあ る.この安定なLWFA電子源の登場によってレーザー航 跡場を加速管のように並べて加速を行う多段レーザー航 跡場加速が現実味を带びてきた，加えて，入射電子ビー ムの位置安定性が飛躍的に向上したことにより従来加速 器で使用されるビームオプティクスをLWFAでも使用で きるようになるため, プラズマの制御だけで取り組んで いたビームパラメータの制御に従来の加速器の技術を取 り入れて行くことも可能になる.

現在, LWFA研究は原理実証の段階から極短高エネル ギー電子バンチを利用する応用研究のフェーズに向かう 過渡期にある。信頼性の高い安定なLWFA駆動超高工ネ ルギー電子加速器や極短パルス電子源が登場すれば, 高 エネルギー加速器科学や超高時間分解電子イメージング 等の物性科学研究を始めとし, 今後は様々な応用が期待 されると同時に, 新しいビーム源を用いた新しい研究が 創出されるであろう。これからのレーザー航跡場加速器 研究の大きな進展を期待したい.

\section{謝 辞}

本稿をまとめるに当たりご協力，ご助言いただきまし た大阪大学兒玉 了祐教授, 佐野智一准教授, Alexei G. Zhidkov特任教授, 島根大学荒河一渡准教授, 日本原子 力研究開発機構神門 正城博士, 森 道昭博士, 小瀧 秀行 博士, Sergei V. Bulanov博士, 高エネルギー加速器研究 機構吉田光宏准教授, 野崎 光昭教授, 小山和義特任研 究員, 名古屋大学山崎 淳助教に梁く感謝いたします。 また, 著者は日本学術振興会から特別研究員奨励制度 (PD No. 23-853)による支援を頂いている.

\section{参考文献}

1) T. Tajima and J. M. Dawson: Phys. Rev. Lett. 43 (1979) 267.

2) S. P. D. Mangles, C. D. Murphy, Z. Najmudin, A. G. R. Thomas, J. L. Collier, A. E. Dangor, E. J. Divall, P. S. Foster, J. G. Gallacher, C. J. Hooker, et al.: Nature 431 (2004) 535; C. G. R. Geddes, Cs. Tóth, J. van Tilborg, E. Esarey, C. B. Schroeder, D. Bruhwiler, C. Nieter, J. Cary, and W. P. Leemans: Nature 431 (2004) 538; J. Faure, Y. Glinec, A. Pukhov, S. Kiselev, S. Gordienko, E. Lefebvre, J.-P. Rousseau, F. Burgy, and V. Malka: Nature 431 (2004) 541; E. Miura, K. Koyama, S. Kato, N. Saito, M. Adachi, Y. Kawada, T. Nakamura, and M. Tanimoto: Appl. Phys. Lett. 86
(2005) 251501; A. Yamazaki, H. Kotaki, I. Daito, M. Kando, S. V. Bulanov, T. Zh. Esirkepov, S. Kondo, S. Kanazawa, T. Homma, K. Nakajima, et al.: Phys. Plasmas 12 (2005) 093101.

3) W. P. Leemans, B. Nagler, A. J. Gonsalves, Cs. Tóth, K. Nakamura, C. G. R. Geddes, E. Esarey, C. B. Schroeder, and S. M. Hooker: Nature Phys. 2 (2006) 696; S. Karsch, J. Osterhoff, A. Popp, T. P. Rowlands-Rees, Z. Major, M. Fuchs, B. Marx, R. Hörlein, K. Schmid, L. Veisz, et al.: New J. Phys. 9 (2007) 415; N. A. M. Hafz, T. M. Jeong, I. W. Choi, S. K. Lee, K. H. Pae, V. V. Kulagin, J. H. Sung, T. J. Yu, K. Hong, T. Hosokai, et al.: Nature Photon. 2 (2008) 571.

4) T. Hosokai, K. Kinoshita, A. Zhidkov, K. Nakamura, H. Kotaki, M. Kando, K. Nakajima, and M. Uesaka: Phys. Plasmas 11 (2004) L57.

5) T. Hosokai, K.Kinoshita, T. Ohkubo, A. Maekawa, M. Uesaka, A. Zhidkov, A. Yamazaki, H. Kotaki, M. Kando, K. Nakajima, et al.: Phys. Rev. E. 73 (2006) 036407.

6) T. Hosokai, K. Kinoshita, A. Zhidkov, A. Maekawa, A. Yamazaki, and M. Uesaka: Phys. Rev. Lett. 97 (2006) 075004.

7) N. Nakanii, T. Hosokai, S. Masuda, A. G. Zhidkov, Z. Jin, Y. Mizuta, H. Nakahara, S. Kajino, K. Makito, A. Nishida, et al.: Proc. International Conference on High Energy Density Sciences 2012 (2012) HED-P12.

8) T. Hosokai, S. Masuda, N. Nakanii, A. Zhidkov, Z. Jin, T. Sano, K. Arakawa, Y. Mizuta, S. Kajino, K. Makito, et al.: Proc. International Conference on High Energy Density Sciences 2012 (2012) HED-6-4.

9) C. E. Clayton, K. A. Marsh, A. Dyson, M. Everett, A. Lal, W. P. Leemans, R. Williams, and C. Joshi: 70 (1993) 37; K. Nakajima: Phys. Plasmas 3 (1996) 2169.

10) M. Uesaka, T. Watanabe, T. Kobayashi, T. Ueda, K. Yoshii, G. Wu, X. Li, Y. Muroya, J. Sugahara, K. Kinoshita, et al.: Radiation Physics and Chem. 60 (2001) 303.

11) D. Umstadter, J. K. Kim, and E. Dodd: Phys. Rev. Lett. 76 (1996) 2073; E. Esarey, R. F. Hubbard, W. P. Leemans, A. Ting, and P. Sprangle: Phys. Rev. Lett. 79 (1997) 2682; V. Malka, S. Fritzler, E. Lefebvre, M.-M. Aleonard, F. Burgy, J.-P. Chambaret, J.-F. Chemin, K. Krushelnick, G. Malka, S. P. D. Mangles, et al.: Science 298 (2002) 1596.

12) T. Hosokai, K. Kinoshita, A. Zhidkov, K. Nakamura, T. Watanabe, T. Ueda, H. Kotaki, M. Kando, K. Nakajima, and M. Uesaka: Phys. Rev. E. 67 (2003) 036407.

13) S. V. Bulanov, F. Pegoraro, A. M. Pukhov, and A. S. Sakharov: Phys. Rev. Lett. 78 (1997) 4205.

14) J. M. Dawson: Phys. Rev. 113 (1959) 383; T. Katsouleas and W. B. Mori: Phys. Rev. Lett. 61 (1988) 90; S.V. Bulanov, V. I. Kirsanov, and A. S. Sakharov: JETP Lett. 53 (1991) 565.

15) S. V. Bulanov, N. Naumova, F. Pegoraro, and J. Sakai: Phys. Rev. E 58 (1998) R5257; H. Suk: J. Appl. Phys. 91 (2002) 487; J. U. Kim, N. Hafz, and H. Suk: Phys. Rev. E 69 (2004) 026409.

16) M. C. Thompson, J. B. Rosenzweig, and H. Suk: Phys. Rev. ST Accel. Beams 7 (2004) 011301.

17) K. Koyama, A. Yamazaki, A. Maekawa, M. Uesaka, T. Hosokai, M. Miyashita, S. Masuda, and E. Miura: Nucl. Instrum. Methods Phys. Res. A 608 (2009) S51.

18) T.-Y. Chien, C.-L. Chang, C.-H. Lee, J.-Y. Lin, J. Wang, and S.-Y. Chen: Phys. Rev. Lett. 94 (2005) 115003.

19) I. Blumenfeld, C. E. Clayton, F.-J. Decker, M. J. Hogan, C. Huang, R. Ischebeck, R. Iverson, C. Joshi, T. Katsouleas, N. Kirby, et al.: Nature 445 (2007) 741.

20) S. P. D. Mangles, A. G. R. Thomas, M. C. Kaluza, O. Lundh, F. Lindau, A. Persson, Z. Najmudin, C.-G. Wahlström, C. D. Murphym, C. Kamperidis, et al.: Plasma Phs. Control. Fusion 48 (2006) B83.

21) E. Miura and S. Masuda: Appl. Phys. Express 2 (2009) 126003.

22) F. Dollor, C. Zulick, A. G. R.Thomas, V. Chvykov, J. Davis, G. Kalinchenko, T. Matsuoka, C. McGuffey, G. M. Petrov, L. Willingale, et al.: Phys. Rev. Lett. 108 (2012) 175005.

23) T. Hosokai, A. Zhidkov, A. Yamazaki, Y. Mizuta, M. Uesaka, and R. Kodama: Appl. Phys. Lett. 96 (2010) 121501.

24) H. Nakahara, T. Hosokai, S. Masuda, N. Nakanii, Y. Mizuta, S. Kajino, K. Makito, A. Zhidkov, and R. Kodama: Proc. International Conference on High Energy Density Sciences 2012 (2012) HED-P20. 
25）梶野祥平, 神門 正城, 水田好雄, 西田明憲, 益田伸一, 小瀧秀行, S. Bulanov, 細貝 知直, 兒玉了祐: 日本物理学
会講演概要集 65 (2010) 23aQJ-1.

\section{レーザーワード}

ラーマー周波数 (Larmor frequency)

磁場からのローレンツカによって荷電粒子が回転する 運動のことをラーマー運動といい, その回転周波数のこ とをラーマー周波数という。 サイクロトロン周波数, ジャイロ周波数とも呼ばれる。 ラーマー周波数は磁場の 強度と荷電粒子の電荷に比例し, 質量に反比例する。 ローレンツ力は磁場の向きと磁場に垂直な速度成分に対 して垂直に働くため, 荷電粒子はエネルギーを保存した
状態で磁場の方向と垂直方向に回転する。磁場の方向に は力が働かないため, 磁力線に沿って等速直線運動を行 い, 結果として軌道は磁力線に巻き付くような螺旋状に なる，文献によってはラーマー周波数は粒子の持つ磁気 モーメントが外部磁場によって歳差運動を起こす時の回 転周波数を表すこともあり注意が必要である.

(中新信彦) 